\title{
Articles
}

The Person and the Challenges

Volume 7 (2017) Number 2, p. 5-22

DOI: http://dx.doi.org/10.15633/pch.2179

Leszek Gęsiak

Jesuit University Ignatianum in Krakow, Poland

\section{Reform of the Vatican media, a difficult search for a new path}

\begin{abstract}
Rapid technological changes, which are mainly the result of the progress in computer technology, in the last decades of the twentieth century, have touched every area of life and have enforced numerous innovations. Modern ways of communication and exchange of information, especially the development of social media, have led to a significant and complex transformation of the traditional media. Practically all media companies around the world, in order to maintain their position on the market, have had to make decisive modifications of their ways of working. On one hand they remained available to the users of traditional media, but on the other hand, they look for effective ways of reaching all those who are using only new ways. Similarly, the Vatican media could not remain indifferent to the issues mentioned above. For several years the Vatican has initiated a process of preparation for a general reform of its media institutions. However, these works have accelerated at a great rate during the pontificate of Pope Francis.

The reform of the Vatican media is not an easy task. It concerns several independent institutions. Each one of them has their own history and way of announcing the Gospel. The widespread computerization, especially the development of the internet and social media, has also forced the Vatican to reflect on new ways of communicating. Among many questions, the most important were about the effectiveness of evangelization through the media, the ways of spreading the Pope's message around the world to as many faithful as possible, and about the costs of necessary investments that would allow further, dynamic development and effective functioning of the Vatican media.
\end{abstract}


After the resignation of Pope Benedict XVI, the problems of the reform of the Roman Curia and the necessary savings were raised again during the discussions of the cardinals on the congregations preceding conclave. It became clear that the structural changes in the Vatican would be one of the challenges which would face the next successor of St. Peter. As from the very start of his pontificate, Pope Francis emphasized the necessity of the deep reform of the Roman Curia. The evaluation of the entire media structure of the Vatican was one of the first reforms to be tackled.

The reform of the Vatican media has already begun. In the Apostolic Letter as a Motu Proprio, published on June 27, 2015, Francis set up the new Vatican dicastery: The Secretariat for Communication. The plan of changes in the Vatican media prepares for the possibility of any difficulties and turbulences. A four-year restructuring process was planned. The year 2015 was dedicated to the creation, elaboration and consolidation of the new Vatican media structure. And it really happened. During the next year, 2016, a common administration for the two major institutions which depended on the new dicastery: the Vatican Radio and the Vatican Television Center, was established. During the year 2017 a similar restructuring process is expected in the next four Vatican media institutions: the Vatican Printing Press, the Photo Service, "L'Osservatore Romano" and the Vatican Publishing House. The process of restructuring of the Vatican media is expected to be completed by the end of 2018. Many details of these changes are raising many questions and concerns, especially among the employees of existing media entities. However, the real questions concern the effectiveness of the new system.

\section{Keywords}

Church, communication, dicastery, Dario Edoardo Viganò, media, Pope Francis, reform, Roman Curia, technological development, Vatican, Vatican Radio.

Rapid technological changes, mainly the result of progress of the computer technology, in the last decades of the twentieth century, have touched every area of life and have enforced numerous innovations. It is difficult to disagree with the thesis that the media are the vanguard of these transformations. Modern ways of communication and exchange of information, especially the development of social media, have led to a significant and complex transformation of the traditional media. Practically all media companies around the world, in order to maintain their position on the market, have had to make decisive modification of their ways of working. On one hand they remain available to the users of traditional media, but on the other hand, they look for effective ways to reach all those who are using only new ways. 
In the face of the issues mentioned above, the Vatican media could not remain indifferent. For decades, they have taken care of the highest level of information for the broadest use of the media in evangelization. This specificity was a reason for which, for several years, the Vatican had initiated a process of preparation for a general reform of its media institutions. These works have accelerated during the pontificate of Pope Francis.

\section{The Vatican media in search of answers to new challenges}

The reform of the Vatican media is not an easy task. It concerns several independent institutions. Each one of them has their own history and way of announcing the Gospel. There is no doubt that one of the biggest and most important media institutions in the Hoy See is the Vatican Radio. It has broadcast since 1931. From that time on this radio station constantly expanded its activities to respond better to the evangelizing challenges of the modern age and to spread the papal message throughout the world to as many people as possible. The Vatican Radio created more than 40 language sections during its 85 years of service. The waves of this radio reached the farthest places of the earth. The Santa Maria di Galeria broadcasting center was set up to provide effective audio transmission using all the available and modern technologies. In fact, the development of new technologies has converted this radio station from a simple broadcast transmitter on waves from Rome, to a huge multimedia corporation which uses satellite facilities and all the possibilities created by internet. It has become a sort of information agency available worldwide through websites, daily multilingual e-mail newsletters, and using fully interactive social media such as Facebook and Twitter.

The second most important, and chronologically the oldest, subject of the Vatican media is the daily "L'Osservatore Romano", whose first issue appeared on July $1,1861 .{ }^{1}$ So it was a long time before the invention of radio waves. It has been the most important source of information flow from the Holy See for decades,

${ }^{1}$ Conf. Il Giornale, "L'Osservatore Romano", www.osservatoreromano.va/it/pages/il-giornale (16.07.2017); see also: M. J. Matelski, Vatican Radio: Propagation by the airwaves, Praeger, Westport-Connecticut-London 1995, p. 51. 
and it was also the official voice of the Popes besides the official documents. ${ }^{2}$ The changes in the media technologies and market needs, that have taken place during more than 150 years, have forced the perpetual transformations of the "L'Osservatore Romano" newspaper. Currently, it is published in seven languages, some of them on a weekly or monthly basis. ${ }^{3}$

The history of the other Vatican media is a bit shorter and generally related to further technological development. These are the Vatican Television Center (Centro Televisivo Vaticano) founded in 1983 and the Vatican Internet Center (Servizio Internet Vaticano). Moreover, various Holy See institutions also ran their own media activities. There were also other entities which, in a broader sense, served the Vatican for spreading information and helping in communication. ${ }^{4}$

The widespread computerization, especially the development of the internet and social media, has also forced the Vatican to reflect on new ways of communicating. Among many questions the most important were about the effectiveness of evangelization through the media, the ways of spreading the Pope's message around the world to as many faithful as possible, and about the costs of necessary investments that would allow further, dynamic development and effective functioning of the Vatican media. There is no doubt that media requires considerable and constant financial resources. Concerns arise around the principle that the Vatican media should not be commercial to remain ideologically independent of all forms of pressure. However, the problem of their funding, whilst striving to maintain the highest technical standards, becomes more and more serious. The expenditures of Vatican media are a significant part of the budget of the Holy See. So it was necessary to reflect on this issue. Benedict XVI created a special commission to make an audit of the various institutions in the Vatican, including the media, to verify their financial transparency. One such audit, which included the evaluation of the development and modernization of Vatican media, was done by McKinsey \& Company. ${ }^{5}$

2 Since 1909, (pontificate of Pius X) all the official documents of the Holy See has been published in Acta Apostolicae Sedis.

${ }^{3}$ Current (July 17th, 2017) “L’Osservatore Romano" editions are: Italian, Spanish, French, English, Portuguese, German and Polish.

${ }^{4}$ It concerns all other institutions that after some time (together with the Vatican Radio, "L'Osservatore Romano", the Vatican Television Center and the Vatican Internet Service) will be covered by a joint restructuring program.

${ }^{5}$ Conf. M. E. Gandolfi, Santa Sede - riforma dei media vaticani: convergenza digitale; intervista a mons. Dario Edoardo Viganò, "Il Regno - Attualità" 4 (2017), p. 75. 


\section{The Pontificate of Pope Francis: towards reorganization}

After the resignation of Pope Benedict XVI, the problems of the reform of the Roman Curia and the necessary financial resources were raised again during the discussions of cardinals on the congregations preceding conclave. It became clear that the structural changes in the Vatican would be one of the challenges the next successor of St. Peter would have to face. Pope Francis, who was then elected, from the very start of his pontificate, emphasized the necessity of the deep reform within the Roman Curia. Listening to the will of the cardinals, he took the problem of reform seriously. To make this reflection broader and more specific, he set up a new advisory body called the Council of Cardinal Advisers, which was supposed to support him in this particular topic. From the very early debates on this forum, the evaluation of the entire media structure of the Vatican was on the agenda.

Following the report prepared by the McKinsey \& Company, another special commission in Vatican was established. It was chaired by Lord Christopher Patten, the last British governor of Hong Kong, and later the Head of BBC British media company. This commission was thus commonly known as Patten's Commission. Its final report suggested various administrative changes. The aim of these suggestions was to simplify cooperation among different institutions, as well as to propose a plan for financial viability. ${ }^{6}$

After various consultations and after accepting the Patten's Commission report, the Council of Cardinal Advisers decided to recommend to the Holy Father the creation of a new administrative body that would deal with the preparation of the all Vatican media reform. ${ }^{7}$ According to this suggestion, Francis established the Media Reform Commission on April 30, 2015. Its presidency was entrusted to the director of the Vatican Television Center Fr. Dario Edoardo Viganò. The committee had four members: Paolo Nusiner, editor-in-chief of the catholic daily "Avvenire"; Fr. Lucio Adrian Ruiz, Head of the Internet Office at the Governorate of Vatican City State; Fr. Antonio Spadaro SJ, Editor-in-chief of the Jesuit magazine "La Civiltà Cattolica" and

${ }^{6}$ Conf. M. E. Gandolfi, Santa Sede - riforma dei media vaticani: convergenza digitale; intervista a mons. Dario Edoardo Viganò, "Il Regno - Attualità" 4 (2017), pp. 75-76.

7 Conf. Vatican Radio, Watykan: utworzenie Komisji ds. Reformy Mediów, http://pl.radiovaticana.va/news/2015/04/30/watykan_utworzenie_komisji_ds_reformy_medi\%C3\%B3w/ 1140863 (16.07.2017). 
Fr. Paul Tighe, Secretary of the Pontifical Council for Social Communications. ${ }^{8}$ The creation of this committee was the first step towards the full restructuring of the media organizations operating at that time in the Vatican. These changes, as frequently emphasized by Fr. Viganò, were envisaged to be like onions, because they were to take place layer by layer. He added also that "every reform, like an onion, causes someone to cry". ${ }^{9}$ Unfortunately, those who are weeping are quite numerous.

\section{Scheme of the reform}

It seems that the reform of the Vatican media, which has already begun, rejects innovations and modifications introduced before. It seems to be more of the beginning of a new process. Reflecting on the data obtained from previous audits and commissions, Fr. Viganò has attempted to "change everything without changing anything". The Church is a particular institution, which therefore calls for a particular reform in the media to establish still better communication with the whole world. At the beginning of the Vatican media reform, Fr. Viganò often spoke about this specificity. "In order to meet the requirements of the Holy Father, we have prepared, and we want to put into practice, the most rigorous indications of modern management research, a new way of communicating internal information, based on an organizational schema that respects what is canonical in the Church and, at the same time, reflects the Synod renewal proposal, which is what Pope Francis wants to strengthen in the universal Church" - he said in the interview made by Carlo Marroni. ${ }^{10}$

The Media Reform Commission was established on June 27, 2015, when Francis published the Apostolic Letter as a Motu Proprio in which he set up

${ }^{8}$ Conf. Vatican Radio, Watykan: utworzenie Komisji ds. Reformy Mediów, http://pl. radiovaticana.va/news/2015/04/30/watykan_utworzenie_komisji_ds_reformy_medi\%C3\%B3w/1140863 (16.07.2017).

9 "Ogni riforma, come la cipolla, fa sempre piangere qualcuno"; conf. Zenit Agency, Viganò e la riforma dei media vaticani: "Il modello è la Disney, il criterio quello apostolico", 27.04.2016, https:/it.zenit.org/articles/vigano-e-la-riforma-dei-media-vaticani-il-modello-e-la-disney-il-criterio-quello-apostolico (16.07.2017).

${ }^{10}$ Conf. C. Marroni, Cosi comunichiamo la Chiesa di Francesco. Nei media vaticani convergenza fra la prospettiva teologica e la rete, "Il Sole 24 ore", 25.02.2016, p. 26, http:// www.ilsole24ore.com/art/commenti-e-idee/2016-02-25/cosi-comunichiamo-chiesa-francesco-063753.shtml?uuid=AC2k8gbC\&refresh_ce=1 (16.07.2016). 
the new Vatican dicastery: The Secretariat for Communication. As the Holy Father emphasized, the current context of communication, characterized by the presence and development of digital media, by the factors of convergence and interaction, demands a rethinking of the Holy See's information system. Speaking of the necessity of reorganizing the communication structure of the Holy See, he emphasized the need for changes towards a unified integration and management. ${ }^{11}$ The document also specifies that the new dicastery will combine all Vatican media organizations active at present: the Pontifical Council for Social Communications, the Holy See Press Office, the Vatican Internet Service, Vatican Radio, the Vatican Television Center, "L'Osservatore Romano", the Vatican Printing Press, the Photo Service and the Vatican Publishing House. ${ }^{12}$ The Motu Proprio also underlined that all these institutions shall continue their respective activities, observing however, the indications provided by the new dicastery. ${ }^{13}$ The Secretariat for Communication, which began its proper functions on 29 June 29, 2015, also assumed responsibility for the Holy See's institutional website and the Twitter service of the Supreme Pontiff. ${ }^{14}$

It is worth mentioning that the people who work for the new dicastery were associated before with various Vatican media. Most of them, at the same time, remain in their former positions. Fr. Dario Edoardo Viganò, who was appointed the Prefect of the Secretariat, was previously a director of the Vatican Television Center, and he also headed the Media Reform Commission established two months earlier. The appointed Secretary of the Media dicastery was Fr. Lucio Adrian Ruiz, Head of the Vatican Internet Office and a former member of the Media Reform Commission. The Director General of the Secretariat appointed was Paolo Nusiner, Editor-in-chief of the Italian Catholic daily "Avvenire" and also a member of the previous Commission. The Deputy Director of the dicastery

${ }^{11}$ Conf. Francesco PP, Litterae Apostolicae Motu Proprio Datae Quibus Secretaria pro Communicatione conditur, "Acta Apostolicae Sedis" 7 (2015), Città del Vaticano, p. 591.

12 Conf. Francesco PP, Litterae Apostolicae Motu Proprio Datae Quibus Secretaria pro Communicatione conditur, "Acta Apostolicae Sedis" 7 (2015), Città del Vaticano, pp. 591-592.

${ }^{13}$ Conf. Francesco PP, Litterae Apostolicae Motu Proprio Datae Quibus Secretaria pro Communicatione conditur, "Acta Apostolicae Sedis" 7 (2015), Città del Vaticano, p. 592.

${ }^{14}$ It's about website www.vatican.va and Twitter account: @pontifex; conf. Francesco PP, Litterae Apostolicae Motu Proprio Datae Quibus Secretaria pro Communicatione conditur, "Acta Apostolicae Sedis" 7 (2015), Città del Vaticano, p. 592. 
is Giacomo Ghisani, the Head of the Bureau of International Relations of Vatican Radio, formerly a member of the Patten's Commission. ${ }^{15}$

The Motu Proprio of Pope Francis established, therefore, a new dicastery and indicated its general purpose and way of proceeding. However, there were no specific guidelines in it. These were to be prepared by the dicastery itself, and later submitted to the Holy Father for approval. One year later, on 6 September 2016 the Pope proclaimed "ad experimentum" for three years, the Statutes of the Secretariat for Communication. Already in the preamble of this document, Francis recalls that the dicastery has been created in order to respond to the current context of communication, characterized by the presence and evolution of digital media, and by factors of convergence and interactivity. This situation requires a reorganization that takes into account the historic development of Holy See's structures of communication. It also moves towards a unified integration and management. ${ }^{16}$ These two principles seem particularly important because, on the one hand, they show that the effectiveness of the functioning of the Vatican media is dependent on their cohesion and the modern and unified system of directing them. But on the other hand, it respects their long and rich historical experience, which is obviously an integral part of the Church history during the last 150 years. This is emphasized again in article $1 \$ 2$ and $\$ 3$ of the Statutes where we read, inter alia, that the Secretariat, unified all the Holy See entities involved in communication in its structure, with respect to relevant operational characteristics, so that the entire system may respond effectively to the needs of the Church's mission of evangelization. ${ }^{17}$ At the same time, however, it will consider new models, technical innovations and forms of communication in order to integrate them into this system. ${ }^{18}$ The Statutes describe in detail the structure of the new dicastery, the way of appointment and the competences

15 Conf. Vatican Radio, Watykan: nowa dykasteria medialna, http://pl.radiovaticana.va/ news/2015/06/27/watykan_nowa_dykasteria_medialna_/1154562 (16.07.2017).

16 Conf. Franciscus PP., Statuto delle Segreteria per la Comunicazione, 22.09.2016, "Bollettino Sala Stampa della Santa Sede", 22.09.2016, Preambolo, https://press.vatican.va/ content/salastampa/it/bollettino/pubblico/2016/09/22/0665/01499.html (16.07.2016).

17 Conf. Franciscus PP., Statuto delle Segreteria per la Comunicazione, 22.09.2016, "Bollettino Sala Stampa della Santa Sede”, 22.09.2016, art. $1 \$ 1$, https://press.vatican.va/content/salastampa/ it/bollettino/pubblico/2016/09/22/0665/01499.html (16.07.2016).

18 Conf. Franciscus PP., Statuto delle Segreteria per la Comunicazione, 22.09.2016, "Bollettino Sala Stampa della Santa Sede”, 22.09.2016, art. $1 \$ 2$, https://press.vatican.va/content/salastampa/ it/bollettino/pubblico/2016/09/22/0665/01499.html (16.07.2016). 
of its superiors, members and managing bodies such as the Committee of the Secretariat for Communications, and the role of the persons responsible for each of its offices. ${ }^{19}$

Pope Francis spoke about it directly to the heads of the Secretariat for Communication on 22 September 2016, when he handed over its Statutes to the Prefect of the Media dicastery. After this meeting, in the interview for the Vatican Radio, Fr. Viganò stressed that the new Statutes are open. It means that they are prepared for possible further development of the Vatican media. He also stressed that the Pope encouraged, in a vigorous way, the realization of the reform of the Holy See's media. This is, as he noted, an irreversible process that should bring all the media to the electronic form. He emphasized, however, that the Church is not only a sociological unit, and therefore no political categories could be applied to it. It needs rather spiritual hermeneutics, and therefore perceives ecclesial events and activities primarily in a spiritual perspective. If this perspective is not a central purpose, it could be converted to the deceptive ideological distortion. So, as Fr. Viganò said, the Secretariat of Communication is a reference point for the world's media, especially for the journalists working in the Vatican. It can help them to talk better about the Holy Father's teaching and about his gestures. ${ }^{20}$

\section{The beginning of change}

In various places around the world, and on various occasions, the Prefect of the Media dicastery repeatedly described the aim and the way of proceeding for the changes that began with the establishment of the Media Reform Commission in April 2015. Very often he compares the whole process to an iceberg. The iceberg that is visible above the water is only a tip of the tips. But, in fact, the most important and the biggest part of it is invisible because it is under water.

19 The Statutes specifies that there will be several such offices (direzione): The General Affairs Office, The Editorial Office, The Holy See Press Office, The Technology Office, The Theological-Pastoral Office; conf. Franciscus PP., Statuto delle Segreteria per la Comunicazione, 22.09.2016, "Bollettino Sala Stampa della Santa Sede", 22.09.2016, art. 8-12, https://press.vatican. $\mathrm{va} /$ content/salastampa/it/bollettino/pubblico/2016/09/22/0665/01499.html (16.07.2016).

${ }^{20}$ Conf. Vatican Radio, Viganò: Papa incoraggia riforma media, processo è irreversibile, http://it.radiovaticana.va/news/2016/09/23/vigan\%C3\%B2_papa_incoraggia_riforma_media_ processo_irreversibile/1260144 (16.07.2016). 
In the new media concept, the Pope must be at the center. And it is a point on which all the Vatican media should be concentrated. "We deal with the Pope, and nothing else, not politics in Rome. We will inform you about the Pope: the rest is not in our competence. We will be able to feature the Pope live: live can be only audio and video, we will have podcasts, photos" - emphasizes Fr. Viganò. ${ }^{21}$

The plan of changes in the Vatican media is prepared for the possibility of any difficulties and turbulences. It was planned to be a four-year restructuring process. The year 2015 was dedicated to the creation, elaboration and consolidation of the new Vatican media structure. And it really happened. First Pope Francis created a Secretariat of Communication. Later he gave the Statutes to the new dicastery. At the same time the previous communication dicastery for media matters - the Pontifical Council for Social Communications - was closed down. There were also changes in the Holy See Press Office which incorporated some departments of the Vatican Radio, mainly responsible for collecting information and documentation. ${ }^{22}$ The Secretariat also started to build a new website which will replace all existing ones in the Vatican.

During the following year, 2016, a common administration for the two major institutions which depend on the new dicastery - the Vatican Radio and the Vatican Television Center - was established. For this to happen, there was a process of transferring the offices and staff from these two institutions to a new structure. This entailed a limitation of their autonomy and the regrouping of the two separate administrations to a common one. All this process happened whilst functioning of the existing entities were maintained consistently. Naturally, these changes have affected these institutions, in particularly the largest one: Vatican Radio. During that time, Vatican Radio programs were broadcast in more than 40 languages and it employed nearly 350 people. To put it in a content, it is

21 "Noi ci occuperemo del Papa, non di altro, non della politica di Roma. Noi comunicheremo il Papa: tutto il resto non è nostra competenza. Troveremo live il Papa: il live potrà essere solo in audio e in video, avremo podcast, foto"; conf.: A. Beramendi, La riforma dei media vaticani nelle parole di mons. Edoardo Viganò, "Iglesia y comunicación", 13.10.2016, https://iglesiaycomunicacion.blogspot.it/2016/10/la-riforma-dei-media-vaticani-nelle.html (16.07.2017).

${ }^{22}$ It refers mainly to the so-called SEDOC - Vatican Radio Documentation Service (Servizio Documentazione della Radio Vaticana). Sandro Magister wrote about these changes and its results among others on his blog in "L'Espresso"; conf. S. Magister, Viganò, riformatore mancato. Con tutti i media vaticani contro, "L’Espresso", 20.02.2017, http://magister.blogautore. espresso.repubblica.it/2017/02/20/vigano-riformatore-mancato-con-tutti-i-media-vaticani-contro (16.07.2017). 
worth noting that all the Vatican media institutions employed approximately 650 people. From 1 January 2017, Vatican Radio officially ceased to exist as an independent entity and became part of the Secretariat for Communication. It started to be an integral part of the Roman Curia. Until that day, Vatican Radio was formally an independent institution associated to the Vatican, but it was not a part of the Roman Curia. From the very beginning of its existence, which is since 1931, the responsibility and care for the Vatican Radio was entrusted to the Society of Jesus. ${ }^{23}$ With the change of the subject of dependence, the Jesuits have formally lost the over-85-year-old responsibility for the operation of this radio station. They also lost the possibility for substantial influence on the program content and style as well as on the broadcasting materials.

A similar restructuring process is expected during 2017 in the next four Vatican media institutions: the Vatican Printing Press, the Photo Service, "L'Osservatore Romano" and the Vatican Publishing House. Thus, initially for the next year, 2018, the institutional consolidation of all the Vatican media is planned. ${ }^{24}$

\section{Vatican media in transition}

The changes in the Vatican media system concern two important aspects: the technological revolution and the new approach to published content. The general idea is that all entities will be synchronized and there will exist only one

${ }^{23}$ It was written clearly in the Vatican Radio Statute: "La Santa Sede affida la conduzione della Radio Vaticana alla Compagnia di Gesù, alla quale compete proporre per la nomina i più alti responsabili dell'Emittente e mettere a disposizione un congruo numero di religiosi idonei ad assicurare il funzionamento dellorganismo sotto la guida e la vigilanza della Segreteria di Stato" (The Holy See entrusts the management of the Vatican Radio to the Society of Jesus, which has to make proposals for the appointments of the highest responsible person in the radio and it has to provide a sufficient number of suitable religious to ensure the functioning of this institution under the guidance and supervision of the Secretariat of State); conf. Statuto della Radio Vaticana, Città del Vaticano, 1995, art. 4.2, p. 6.

24 The Prefect of the Secretariat for Communication talked about it in an interview for the magazine "Regno-attualità"; conf. M. E. Gandolfi, Santa Sede - riforma dei media vaticani: convergenza digitale; intervista a mons. Dario Edoardo Viganò, "Il Regno - Attualità" 4 (2017), p. 76; see also: A. Beramendi, La riforma dei media vaticani nelle parole di mons. Edoardo Viganò, "Iglesia y comunicación", 13.10.2016, https://iglesiaycomunicacion.blogspot.it/2016/10/ la-riforma-dei-media-vaticani-nelle.html (16.07.2017). 
place, the information center (Content hub) ${ }^{25}$, where any incoming information such as: sounds, photos, videos, news, journalistic information or social media messages will be collected. The Prefect of the Media dicastery explained it as follows: "The reform will have its main technological core on the web with the following structure: instead of the news.va web sites and the web sites of Vatican Radio and Vatican Television, there will be only one Content hub, one multilingual portal. There will be set all videos, texts (except for the official documentation, which will be still available on the vatican.va website), photos and podcasts. These materials should be created from the very beginning with the idea that they are designed for all types of media, what we are calling 'a trans-media approach' (whereas, so far, the tendency has been to post on the web, materials in languages and formats related to traditional communication technologies)" ${ }^{26}$

The operating center of the whole system will be the central place of the so-called CEM (Centro Editoriale Multimediale - Multimedia Editorial Center). It is supposed to create ready-made materials and to distribute them in different ways. The system permits that all information would be available at any time, at any place and with any type of receiver. It means that the Vatican Radio, Vatican Television Center and "L'Osservatore Romano" will no longer create their own information. The information will be available only in the main command center, through various channels and media, and can be distributed at any time to all available entities: radio, television, multimedia, websites, social platforms etc. The content will be created in different languages and it will preserve and respect the cultural diversity of the audience.

The statute of the new dicastery envisages the creation of five key offices (direzione) with their respective directors. Up to now, however, only four of

${ }^{25}$ Conf. F. Domingues, Vatican communications czar says losing money "robs the poor", "Crux" 10.02.2017, https://cruxnow.com/interviews/2017/02/10/vatican-communications-czar-says-losing-money-robs-poor (16.07.2017).

26 "La riforma avrà nella Rete la sua dorsale tecnologica centrale, con questa architettura: al posto del sito Internet news.va e di quelli di Radio vaticana e del CTV vi sarà un unico content hub, un portale multilinguistico dove trovare video, testi (non la documentazione ufficiale, che continuerà a essere reperibile sul sito vatican.va), foto e podcast. Questi materiali dovranno essere prodotti sin dallorigine sapendo che sono destinati a tutti i media, secondo quello che chiamiamo un approccio transmediale (mentre prima la tendenza era quella di trasferire in Rete linguaggi e formati legati alle tecnologie di comunicazione tradizionali)”. M. E. Gandolfi, Santa Sede - riforma dei media vaticani: convergenza digitale; intervista a mons. Dario Edoardo Viganò, "Il Regno - Attualità" 4 (2017), p. 76. 
them were appointed, because the Editorial Office (La direzione editoriale) remained ad interim directly in the hands of the Prefect of the dicastery himself. It seems, therefore, that in the present transitional phase, the control over this unit is particularly strengthened. The Head of the dicastery, in an interview for the Italian daily "Avvenire", explained that it was necessary to move from the idea of individual media to a single media center. At this initial stage, what is crucial is a very good understanding of the flow of messages. Also, the special group of the journalists needs to be properly prepared. They have to study how to create their materials to respond to all the needs of the different types of media. ${ }^{27}$

The reference figure for media changes in the Vatican is, of course, the Prefect of the Secretariat for Communication, Fr. Dario Viganò. On various occasions he revealed the details of the media transformation in the Holy See. He emphasizes that the reform defines two criteria: apostolic and economic. "The Vatican media exists to communicate the evangelical message and teaching of the Pope and to make it more accessible to the people. This is a main criterion and we want to preach it. But, of course, we have to consider our possibilities which are not unlimited" - he said in one of his interviews. ${ }^{28} \mathrm{He}$ also referred to the second criterion: "The second priority criterion is how to use the funds. On the one hand there is an apostolic criterion, on the other hand, we have to be very careful of our attitude in using money, because it is impossible, or unthinkable, to use the

${ }^{27}$ Fr. Viganò said: "La Direzione editoriale in questo momento vive una fase di simulazione fino a quando non si avvierà il vero e proprio content hub. Infatti la riforma supera l'idea dei singoli media per giungere a un unico centro di produzione multimediale - il content hub appunto - di testi, immagini, audiovisivi e podcast radiofonici in multilingua. In tale passaggio è molto importante comprendere a fondo i processi di flusso delle notizie. È necessario inoltre approntare una task force di giornalisti che sappia individuare issues esterni e interni per immetterli nel flusso delle notizie" (The Editorial Office is currently experiencing a simulation phase until the Content hub will work fully and properly. In fact, the reform goes beyond the idea of individual media to reach a single multimedia production center - the Content hub the texts, images, audiovisuals and radio podcasts in various languages. At this moment it is very important to fully understand the processes of flow of the news. It is also necessary to set up a task force of journalists who will be able elaborate the external and internal issues and know how to put them to the streaming of the news); conf. G. Cardinale, Viganò: "Cosi la Chiesa cambia comunicazione», "Avvenire", 26.09.2016, https://www.avvenire.it/chiesa/pagine/ intervista-a-don-vigano (16.07.2017).

${ }^{28}$ Conf. F. Domingues, Vatican communications czar says losing money "robs the poor”, "Crux" 10.02.2017, https://cruxnow.com/interviews/2017/02/10/vatican-communications-czar-says-losing-money-robs-poor (16.07.2017). 
funds that people give for charity or for the poor to cover our expenses". ${ }^{29}$ So in this context, as Fr. Viganò said, the issue of reducing the cost of maintaining the entire media structure is extremely important. And this is one of the reasons for the integration of multiple institutions and their centralization using a common administration. It will reduce bureaucracy and, consequently, it will decrease the costs of its maintenance. ${ }^{30}$

So, the aim is to create a kind of media consortium that will be efficiently managed by minimized administration. It will also help to make an effective influence for the Vatican media customers. The Head of the dicastery often compares the new structure to the Disney consortium which is based on this kind of Content hub. Fr. Viganò claims that, in the Vatican, the Disney model will be obviously adapted according to the fundamental criterion of the apostolic role of the media. The point is that all the expenses and the commitment of each person should be carefully analyzed. The main question is whether the Gospel and the teaching of the Holy Father reach the hearts and minds of the people. Everything must be fully professional, starting with the ethical dimension. A good journalist should not make mistakes. ${ }^{31}$

However, there is an immediate accusation that the purpose of the Walt Disney Company, as well as many others global media companies, is primarily to achieve the highest profits that such companies should receive. So the question arises: how can it work with the evangelizing mission of the Church as a purpose? This kind of mission should be free of such temptation! Fr. Viganò believes, however, that some model of the new Vatican media is needed, although it is obvious that the Disney one will require a special adaptation. ${ }^{32}$

29 Conf. F. Domingues, Vatican communications czar says losing money "robs the poor", "Crux" 10.02.2017, https://cruxnow.com/interviews/2017/02/10/vatican-communications-czar-says-losing-money-robs-poor (16.07.2017).

${ }^{30}$ Fr. Viganò has made a comparison to the saving programs which took place in some dioceses: "The diocese can put together radio, newspaper, weekly and possibly television. It will reduce the bureaucracy and the size of the administration and offices. It does not mean that we have to see our reform in the same way. We look on that for to be able to say that if they do it, we also can try to do it"; conf. F. Domingues, Vatican communications czar says losing money "robs the poor", "Crux" 10.02.2017, https://cruxnow.com/interviews/2017/02/10/ vatican-communications-czar-says-losing-money-robs-poor (16.07.2017).

${ }^{31}$ Conf. Zenit Agency, Viganò e la riforma dei media vaticani: "Il modello è la Disney, il criterio quello apostolico", 27.04.2016, https:/it.zenit.org/articles/vigano-e-la-riforma-dei-media-vaticani-il-modello-e-la-disney-il-criterio-quello-apostolico (16.07.2017).

${ }^{32}$ Fr. Vigano said: “The problem would be if we didn't have a model. The apostolic criterion can't justify ignorance with respect to managerial competence. That has to be very clear. Good 
Another very serious challenge facing the present reform is the adaptation of the Vatican media to the real needs of today's world. Fr. Viganò has emphasized that the reduction of the production costs requires a change and modernization of the journalists' work. In addition, in today's world, traditional radio, television and newspapers are becoming more and more available through web pages and social media. It means that, in today's world, everyone can relate any event on his blog or Twitter, one can describe whatever one is able to see. One can also put, onto the network, videos, photos or sound recordings and in that way becoming a multimedia reporter. These are the serious challenges of the digital and virtual world in which a huge part of the population of the world is growing nowadays. The church has to notice these changes. "We have to learn to discern well in the digital realm. It's clear that digital media offer occasions to meet people. The Church lives where real men and women live, and therefore it's ready to help from this point of view" - said the Head of the Media dicastery. ${ }^{33}$

\section{The voice of Pope Francis}

There is no doubt that Pope Francis himself directly contributed to the rapid acceleration of the reform of the Vatican media. The encouragement of the Congregation of the Cardinals before the election of successor of Benedict XVI: that a new Pope should begin a reform of the Roman Curia, was certainly an important impulse. During the pontificate of Francis we can see the deep analysis of the Vatican's economic situation. The Pope feels the need to take concrete steps towards serious savings. These factors coincided with changes in the media of the Holy See, especially within the main and the largest of its subject: the Vatican Radio. There is where the concentration of the first changes took place. It seems that the comparison made by Fr. Viganò, that the reform is

will and an apostolic criterion don't authorize anyone to waste money. Choosing a model, even if it comes from a strongly commercial environment, helps to build a vision of "work flow" to give maximum value to competence and professionality, with the aim of making communications efficient and containing costs. The point is to have a model, and I'm not saying this is necessarily the best, but to me it is", conf. F. Domingues, Vatican communications czar says losing money "robs the poor", "Crux" 10.02.2017, https://cruxnow.com/interviews/2017/02/10/ vatican-communications-czar-says-losing-money-robs-poor (16.07.2017).

33 Conf. F. Domingues, Vatican communications czar says losing money "robs the poor", "Crux" 10.02.2017, https://cruxnow.com/interviews/2017/02/10/vatican-communications-czar-says-losing-money-robs-poor (16.07.2017). 
like an onion, was the most accurate here. Radio dismantling happens in layers. So too it is because tear appeared on the faces of many, in spite of the euphoric, optimistic and bright visions of the future.

Although the reform has not entered yet into the decisive phase, the price that the Church will pay for it seems to be very high. For many of the workers of the Vatican media institutions the target of the reform is still unclear. On the other hand, it seems that the reform is going ahead according to its original plan. On several occasions, the Holy Father already confirmed the validity of the adopted line of the reform. He also expressed full support for its implementation. This voice was especially clear in his address to the First Plenary Session of the Secretariat for Communications which took place in the Vatican on 4 May, 2017, almost two years after the establishment of this dicastery. Francis strongly emphasized that the reform was irreversible. He also recalled that its purpose is not just the coordination or merger of existing media institutions but to build a new organism from the beginning. "Reform is not simply a whitewash. Reform means to give to the things a new form, organizing them in a new way. You have to do it intelligently, gently, but with a bit of - please forgive me a word - with a bit of «violence»", but a good violence, to carry out the reform" - pointed Holy Father. ${ }^{34}$

In the Pope's speech there was also a reference to one of the main elements of the changes - digital convergence. Its aim is to elaborate new ways of communicating the Gospel of mercy to all people among different cultures, through the media in which the new context of the digital culture is available to our contemporaries. "In the past, every way of communication had its own channels. Each way of expressing had its own medium: written words - newspapers or books; pictures photographs; whatever was moving - cinema and television; spoken words and music - radio and discs. Today all ways of communication are transmitted using a unique binary code" - said Francis. ${ }^{35}$ He also urged that all actions taken

34 "Riforma non è "imbiancare" un po' le cose: riforma è dare un'altra forma alle cose, organizzarle in un altro modo. E si deve fare con intelligenza, con mitezza, ma anche, anche permettetemi la parola - con un po' di "violenza", ma buona, della buona violenza, per riformare le cose"; conf. Francesco, Discorso del Santo Padre Francesco al partecipanti alla Plenaria della Segreteria per la Comunicazione, 4.05.2017; http://w2.vatican.va/content/francesco/it/ speeches/2017/may/documents/papa-francesco_20170504_plenaria-segreteria-comunicazione. html (16.07.2017).

35 "Nel passato ogni modalità comunicativa aveva i propri canali. Ogni forma espressiva aveva un proprio medium: le parole scritte, il giornale o i libri, le immagini le fotografie e quelle in movimento il cinema e la televisione, le parole parlate e la musica, la radio e i CD. Tutte queste forme di comunicazione oggi sono trasmesse con un unico codice che sfrutta il sistema 
should always have a clear direction, which is the apostolate and missionary dimension of the Church. "I ask you that your guiding criterion is apostolate, missionary, with a special attention to the situation marked by indigence, poverty and difficulties, to be aware that these areas must also be reached to help them with the appropriate measure. In this way it will be possible to bring the Gospel to everyone, to appreciate the human resources without using the media of the local Churches, and, at the same time, to support those ecclesial communities that need it most" - said the Holy Father. ${ }^{36}$

The process of restructuring of the Vatican media is expected to be completed by the end of 2018. As mentioned, this is a very difficult process. It is being executed with great determination, because it is the will of the Pope. However, it does not change the fact that these changes are raising many questions and concerns, especially among the employees of existing media entities. They go beyond concerns regarding their employment. The Holy Father himself, on many occasions, reassured that during the time of reform there will not be dismissals. The real questions concern the effectiveness of the new system. Is it true that with the help of the most modern technology the Papal message will actually reach where it is expected, especially where it is the only possible voice of the Church? It is obviously not possible to carry out a broader analysis and evaluation of the efficiency of the reform before it is completed. For this we need to wait until the new structure of the Vatican media is completely in place.

\section{Bibliography}

Beramendi A., La riforma dei media vaticani nelle parole di mons. Edoardo Viganò, "Iglesia y comunicación", 13.10.2016, https://iglesiaycomunicacion.blogspot.it/2016/10/ la-riforma-dei-media-vaticani-nelle.html (16.07.2017).

binario"; conf.: Francesco, Discorso del Santo Padre Francesco al partecipanti alla Plenaria della Segreteria per la Comunicazione, http://w2.vatican.va/content/francesco/it/speeches/2017/may/ documents/papa-francesco_20170504_plenaria-segreteria-comunicazione.html (16.07.2017).

36 "Vi chiedo inoltre che il criterio-guida sia quello apostolico, missionario, con una speciale attenzione alle situazioni di disagio, di povertà, di difficoltà, nella consapevolezza che anche queste oggi vanno affrontate con soluzioni adeguate. Così diventa possibile portare il Vangelo a tutti, valorizzare le risorse umane, senza sostituirsi alla comunicazione delle Chiese locali e, al tempo stesso, sostenendo le comunità ecclesiali che più hanno bisogno"; conf.: Francesco, Discorso del Santo Padre Francesco al partecipanti alla Plenaria della Segreteria per la Comunicazione, http://w2.vatican.va/content/francesco/it/speeches/2017/may/documents/ papa-francesco_20170504_plenaria-segreteria-comunicazione.html (16.07.2017). 
Cardinale G., Viganò: "Cosi la Chiesa cambia comunicazione», "Avvenire”, 26.09.2016, https://www.avvenire.it/chiesa/pagine/intervista-a-don-vigano (16.07.2017).

Domingues F., Vatican communications czar says losing money "robs the poor", "Crux" 10.02.2017, https://cruxnow.com/interviews/2017/02/10/vatican-communications-czar-says-losing-money-robs-poor (16.07.2017).

Gandolfi M. E., Santa Sede - riforma dei media vaticani: convergenza digitale; intervista a mons. Dario Edoardo Viganò, "Il Regno - Attualità" 4 (2017), p. 75-77.

Magister S., Viganò, riformatore mancato. Con tutti i media vaticani contro, "L'Espresso", 20.02.2017, http://magister.blogautore.espresso.repubblica.it/2017/02/20/vigano-riformatore-mancato-con-tutti-i-media-vaticani-contro (16.07.2017).

Marroni C., Cosi comunichiamo la Chiesa di Francesco. Nei media vaticani convergenza fra la prospettiva teologica e la rete, "Il Sole 24 ore", 25.02.2016, p. 26, http://www. ilsole24ore.com/art/commenti-e-idee/2016-02-25/cosi-comunichiamo-chiesa-francesco-063753.shtml?uuid=AC2k8gbC\&refresh_ce=1 (16.07.2017).

Matelski M. J., Vatican Radio: Propagation by the airwaves, Praeger, Westport-Connecticut-London 1995.

Pope Francis, Discorso del Santo Padre Francesco al partecipanti alla Plenaria della Segreteria per la Comunicazione, 4.05.2017; http://w2.vatican.va/content/francesco/ it/speeches/2017/may/documents/papa-francesco_20170504_plenaria-segreteria-comunicazione.html (16.07.2017).

Pope Francis, Litterae Apostolicae Motu Proprio Datae Quibus Secretaria pro Communicatione conditur, "Acta Apostolicae Sedis" 7 (2015), Città del Vaticano, p. 591-592.

Pope Francis, Statuto delle Segreteria per la Comunicazione, 22.09.2016, "Bollettino Sala Stampa della Santa Sede”, 22.09.2016, Preambolo, https://press.vatican.va/content/ salastampa/it/bollettino/pubblico/2016/09/22/0665/01499.html (16.07.2016).

Statuto della Radio Vaticana, Città del Vaticano, 1995, art. 4.2, p. 6.

Vatican Radio, Viganò: Papa incoraggia riforma media, processo è irreversibile, http:// it.radiovaticana.va/news/2016/09/23/vigan\%C3\%B2_papa_incoraggia_riforma_ media_processo_irreversibile/1260144 (16.07.2016).

Vatican Radio, Watykan: nowa dykasteria medialna, http://pl.radiovaticana.va/ news/2015/06/27/watykan_nowa_dykasteria_medialna_/1154562 (16.07.2017).

Vatican Radio, Watykan: utworzenie Komisji ds. Reformy Mediów, http://pl.radiovaticana.va/ news/2015/04/30/watykan_utworzenie_komisji_ds_reformy_medi\%C3\%B3w/1140863 (16.07.2017).

Zenit Agency, Viganò e la riforma dei media vaticani: "Il modello è la Disney, il criterio quello apostolico", 27.04.2016, https://it.zenit.org/articles/vigano-e-la-riforma-dei-media-vaticani-il-modello-e-la-disney-il-criterio-quello-apostolico (16.07.2017).

http://www.osservatoreromano.va/it/pages/il-giornale (16.07.2017). 